\title{
MODEL PEMBELAJARAN PROBLEM BASED LEARNING (PBL): EFEKNYA TERHADAP PEMAHAMAN KONSEP DAN BERPIKIR KRITIS
}

\section{PROBLEM BASED LEARNING (PBL) LEARNING MODEL: THE EFFECT ON UNDERSTANDING OF CONCEPT AND CRITICAL THINKING}

\author{
Eka Yulianti ${ }^{1}$, Indra Gunawan ${ }^{2}$ \\ ${ }^{1}$ SMP Assahil Lampung Timur \\ ${ }^{2}$ Prodi Pendidikan Fisika Fakultas Tarbiyah dan Keguruan Universitas Islam Negeri Raden Intan Lampung \\ E-mail: ekayulianty89@gmail.com
}

Diterima: 17 September 2019. Disetujui: 10 Oktober 2019. Dipublikasikan: 29 November 2019

\begin{abstract}
This study aims to investigate the effectiveness of the learning problem based learning (PBL) model against understanding of concepts and critical thingking of students on senior high school temperature and heat material. Subjects in this study were students class X SMA N 1 waway karya lampung timur amounted to 70 student. The method used is a quasi experimental design with pretetsposttest control design. Data understanding of concepts and critical thingking were collected by instruments test essay questions. The obtained data then analyzed by using multivariate (MANOVA) test. The results of the analysis with spss 17.00 program show that there is a significant effect in applying the guided of the learning problem based learning (PBL) model against understanding of concepts and critical thingkingof students. The gain score of understanding of concepts in experimental class was 0,51and and the gain score in control class was 0,31 while the gain score of critical thingking in experimental class was 0,58 and the gain score in control class was0,31. The effectiveness of the use models of problem based learning better in improving of understanding of concepts and critical thingking of students, it can be seen from the value obtained effect size of 0,66. In addition,based on manova test, the significance score of both understanding of concepts and critical thingking is less than 0.005. It can be concluded that there are significant effect of guided problem based learning and understanding of concepts and critical thingking of students on senior high school.
\end{abstract}

Keywords: problem based learning, understanding of concepts, critical thinking

Abstrak: Penelitian ini bertujuan untuk mengetahui efektivitas model pembelajaran problem based learning (PBL) terhadap pemahaman konsep dan berpikir kritis peserta didik SMA pada materi suhu dan kalor. Subjek pada penelitian ini adalah peserta didik kelas X SMA N 1 waway karya lampung timur berjumlah 70 orang peserta didik. Metode penelitian yang dipilih yakni quasi eksperiment dengan desain pretets-posttest control design.Data pemahaman konsep dan berpikir kritis dikumpulkan melalui instrumen tes soal essay. Data yang diperoleh kemudian di analisis menggunakan uji multivariate (MANOVA). Hasil analisis data dengan program spss 17.00 menunjukkan bahwa terdapat pengaruh penerapan model pembelajaran problem based learning terhadap pemahaman konsep dan berpikir kritis peserta didik. Nilai gain pemahaman konsep kelas eksperimen sebesar 0,51 dan nilai gain kelas kontrol sebesar 0,31 sedangkan nilai gain berpikir kritis kelas eksperimen sebesar 0,58 dan nilai gain kelas kontrol sebesar 0,31 . Efektivitas penggunaan model PBL lebih efektif dalam meningkatkan pemahaman konsep dan berpikir kritis peserta didik, ditunjukkan dengan nilai effect size pemahaman konsep sebesar 0,36 dan nilai effect size berpikir kritis sebesar 0,66. Selain itu berdasarkan hasil uji manova, baik nilai signifikansi pemahaman konsep maupun nilai signifikansi kurang dari 0,005 sehingga dapat disimpulkan bahwa terdapat pengaruh penerapan model PBL terhadap pemahamman konsep dan berpikir kritis peserta didik SMA.

(C) 2019 Unit Riset dan Publikasi Ilmiah FTK UIN Raden Intan Lampung

Kata Kunci: problem based learning, pemahaman konsep, berpikir kritis 


\section{PENDAHULUAN}

Pendidikan telah berlangsung sejak awal peradaban dan budaya manusia. Bentuk dan cara pendidikan itu telah mengalami perubahan, sesuai dengan perubahan zaman dan tuntutan kebutuhan. (yusufhadi miarso, 2004). Pendidikan di indonesia merupakan bagian dari upaya mencerdaskan kehidupan bangsa dan meningkatkan kualitas sumber daya manusia.(Siregar, 2016) .Dewasa ini, pendidikan telah mengalami perkembangan yang sangat pesat, informasi dan komunikasi juga berkembang setiap saat. Hal ini mengakibatkan adanya persaingan yang sangat ketat di dunia pendidikan, untuk menghadapinya diperlukan kualitas pendidik yang bermutu dan profesional. (Zalia Muspita, I. W. Lasmawan, 2013). Seorang pendidik hanya bertindak sebagai motivator dan fasilitator, namun pada akhir kegiatan pendidik juga mengevaluasi dan memberikan kesimpulan dari kegiatan pembelajaran. Banyak sekolah di indonesia telah menggunakan kurikulum baru yaitu kurikulum 2013. Di dalam kurikulum 2013 terdapat beberapa prinsip pembelajaran yang di harapkan menunjang mutu pendidikan indonesia. Di antara prinsip-prinsip pada kurikulum 2013 yaitu mendorong siswa menjadi peserta didik yang aktif. (Parasamya \& Wahyuni, 2017). Selain aktif peserta didik harus paham konsep dan berpikir kritis dalam setiap mata pelajaran. Termasuk pelajaran sains, Fisika merupakan salah satu mata pelajaran sains yang sangat erat kaitannya dengan kehidupan seharihari.(Saregar, 2016).

Berdasarkan hasil pra penelitian dan wawancara guru fisika di SMA N 1 waway karya lampung timur, di temukan masalah dalam proses pembelajaran khususnya peserta didik kelas X MIA. Pada saat proses pembelajaran berlangsung, terdapat beberapa peserta didik tidak memperhatikan materi yang di sampaikan oleh pendidik seperti, berbicara dengan teman sebelahnya, sering izin ke toilet, mengantuk, dan peserta didik cenderung pasif. Selain kondisi peserta didik masalah juga muncul pada pendidik, yaitu pendidik masih mendominasi kelas, cenderung ceramah, kurang memberi motivasi, dan rendahnya volume suara pendidik dalam penyampaian materi. Peserta didik hanya mencatat apa yang disampaikan pendidik tanpa ada respon balik terhadap apa yang di catat atau disampaikan pendidik. Jika kondisi kelas seperti ini, maka materi yang disampaikan oleh pendidik tidak dapat di terima dengan baik oleh peserta didik.

Dampak dari kondisi pembelajaran tersebut, muncul masalah baru bagi peserta didik yaitu masih rendahnya kemampuan berpikir kritis peserta didik, Hal ini terlihat ketika peserta didik diberikan tugas untuk mengerjakan soal latihan sebagian besar peserta didik kurang tepat dalam mengerjakan soal sehingga banyak jawaban peserta didik yang salah. Ini menunjukkan masih rendahnya kemampuan berpikir kritis peserta didik dalam mengerjakan soalsoal latihan fisika, kurang optimalnya kemampuan berpikir kritis peserta didik menyebabkan hasil belajar peserta didik juga rendah. Mengingat bahwa kemampuan berpikir kritis untuk peserta didik kelas $\mathrm{X}$ harus sudah diterapkan sejak dini. Selain berpikir kritis peserta didik juga mengalami kesulitan dalam memahami konsep-konsep fisika, dalam proses pembelajaran peserta didik dihadapkan dengan sejumlah materi yang harus dihafalkan tanpa diberi kesempatatan untuk memahami materi yang dipelajari, sehingga peserta didik hanya belajar tetapi kurang memahami proses pembelajaran itu sendiri. Banyak peserta didik dalam proses belajar hanya menghafal konsep-konsep, mencatat, 
mendengarkan, pasif, dan jarang menggunakan pengetahuan awal sebagai dasar perencanaan pembelajaran, kondisi inilah yang menyebabkan rendahnya hasil belajar peserta didik. Pemahaman konsep sangat penting dengan tujuan agar peserta didik dapat mengingat konsep-konsep materi yang mereka pelajari sebelumnya, sehingga proses belajar akan menjadi lebih bermakna.

Peran pendidik dalam proses pembelajaran sangat berpengaruh, secara umum proses pembelajaran pada mata pelajaran fisika di kelas X MIA masih dominan berpusat pada pendidik (student centered), serta pendidik masih menggunakan metode ceramah, demonstrasi dan model pembelajaran yang membuat peserta didik kurang aktif dalam proses pembelajaran. Model pembelajaran yang di butuhkan peserta didik yaitu yang mampu menghasilkan kemampuan untuk belajar. (Ahmad, Fandi \& Aminah, 2015). Setiap model pembelajaran memiliki struktur tujuan pembelajaran yang berbeda-beda tetapi pada intinya sama untuk mencapai hasil belajar yang maksimal. Banyaknya model pembelajaran yang dapat membangun proses berpikir ilmiah peserta didik antara lain: Inquiry, POE, problem based structure, discovery learning, project based learning (PjBL), discovery learning, dan problem based learning (PBL). Salah satu model pembelajaran yang dapat di kembangkan dan di adopsi untuk menempatkan peserta didik sebagai pusat pembelajaran dengan menerapankan model problem based learning (PBL). (didik juliawan, n.d. 2015). Model pembelajaran problem based learning (PBL) adalah proses pembelajaran yang memiliki ciri-ciri pembelajaran di mulai dengan pemberian masalah yang memiliki konteks dengan dunia nyata, pembelajaran berkelompok aktif, merumuskan masalah dan mengidentifikasi kesenjangan pengetahuan mereka, mempelajari dan mencari sendiri materi yang terkait dengan masalah dan solusi dari masalah tersebut. (M Taufik Amir, 2015).

\section{LANDASAN TEORI}

\section{Model Problem Based Learning}

Efektivitas pembelajaran secara konseptual dapat diartikan sebagai perlakuan dalam proses pembelajaran yang berdampak pada keberhasilan usaha atau tindakan terhadap hasil belajar peserta didik. (Rifa'i, 2013). Efektivitas dalam penelitian ini berhubungan dengan model problem based learning (PBL) terhadap pemahaman konsep dan berpikir kritis peserta didik SMA pada mata pelajaran fisika.

Model pembelajaran merupakan suatu sistem, yang terdiri atas berbagai komponen yang saling berhubungan satu sama lainnya. (rusman, 2010). Model pembelajaran problem based learning (PBL) merupakan pembelajaran yang menitik beratkan pada kegiatan pemecahan masalah. (Dasa ismaimuza, n.d. 2010). Dengan maksud peserta didik secara aktif mampu mencari jawaban atas masalah-masalah yang di berikan pendidik. Dalam hal ini pendidik lebih banyak sebagai mediator dan fasilitator untuk membantu peserta didik dalam mengkonstruksi pengetahuan secara aktif. (Siregar, 2016).

Menurut Dutch dalam M. taufik amar (1994) menyatakan bahwa PBL merupakan metode instruksional yang menantang peserta didik agar "belajar dan untuk belajar", bekerja sama dengan kelompok untuk mencari solusi bagi masalah yang nyata. Masalah ini di gunakan untuk mengaitkan rasa keingintahuan serta kemampuan analisis peserta didik dan inisiatif atas materi pembelajaran. PBL mempersiapkan peserta didik untuk berpikir kritis dan analitis, dan untuk mencari serta menggunakan sumber pelajaran yang sesuai. 
Tabel 1. Langkah-langkah Problem Based Learning

\begin{tabular}{|c|c|c|}
\hline No & Indikator & Kegiatan guru \\
\hline 1. & $\begin{array}{l}\text { Orientasi } \\
\text { peserta didik } \\
\text { pada masalah }\end{array}$ & $\begin{array}{l}\text { Menjelaskan tujuan } \\
\text { pembelajaran, } \\
\text { menjelaskan logistik } \\
\text { yang diperlukan, dan } \\
\text { memotivasi peserta didik } \\
\text { terlibat pada aktivitas } \\
\text { pemecahan masalah. }\end{array}$ \\
\hline 2. & $\begin{array}{l}\text { Mengorganisa } \\
\text { sikan peserta } \\
\text { didik untuk } \\
\text { belajar }\end{array}$ & $\begin{array}{l}\text { Membantu peserta didik } \\
\text { mendefinisikan dan } \\
\text { mengorganisasikan tugas } \\
\text { belajar yang } \\
\text { berhubungan dengan } \\
\text { masalah tersebut. }\end{array}$ \\
\hline 3. & $\begin{array}{l}\text { Membimbing } \\
\text { pengalaman } \\
\text { individual atau } \\
\text { kelompok }\end{array}$ & $\begin{array}{l}\text { Mendorong peserta didik } \\
\text { untuk mengumpulkan } \\
\text { informasi yang sesuai, } \\
\text { melaksanakan } \\
\text { eksperimen untuk } \\
\text { mendapatkan penjelasan } \\
\text { dan pemecahan masalah. }\end{array}$ \\
\hline 4. & $\begin{array}{l}\text { Mengembangk } \\
\text { an dan } \\
\text { menyajikan } \\
\text { hasil karya }\end{array}$ & $\begin{array}{l}\text { Membantu peserta didik } \\
\text { dalam merencanakan dan } \\
\text { menyiapkan karya yang } \\
\text { sesuai seperti laporan } \\
\text { dan membantu mereka } \\
\text { untuk berbagai tugas } \\
\text { dengan temannya. }\end{array}$ \\
\hline 5. & $\begin{array}{l}\text { Menganalisis } \\
\text { dan } \\
\text { mengevaluasi } \\
\text { proses. }\end{array}$ & $\begin{array}{l}\text { Membantu peserta didik } \\
\text { untuk melakukan refleksi } \\
\text { atau evaluasi terhadap } \\
\text { penyelidikan mereka dan } \\
\text { proses yang mereka } \\
\text { gunakan. }\end{array}$ \\
\hline
\end{tabular}

Kelebihan Model Pembelajaran PBL sebagai berikut:

1. Pemecahan masalah dalam PBL cukup bagus untuk memahami isi pelajaran

2. Pemecahan masalah berlangsung selama proses pembelajaran menantang kemampuan siswa serta memberikan kepuasan kepada siswa.

3. PBL dapat meningkatkan aktivitas pembelajaran.

4. Membantu proses transfer siswa untuk memahami masalah-masalah dalam kehidupan sehari-hari.

5. Membantu siswa mengembagkan pengetahuannya dan membantu siswa untuk bertanggung jawab atas pembelajarannya sendiri.
6. Membantu siswa untuk memahami hakekat belajar sebagai cara berfikir bukan hanya sekedar mengerti pembelajaran oleh guru berdasarkan buku teks.

7. PBL menciptakan lingkungan belajar yang menyenangkan dan di sukai siswa.

8. Memungkinkan aplikasi dalam dunia nyata.

9. Merangsang siswa untuk belajar secara kontinu.

Kekurangan Model Pembelajaran PBL sebagai berikut:

1. Apabila siswa mengalami kegagalan atau kurang percaya diri dengan minat yang rendah maka siswa enggan untuk mencoba lagi.

2. PBL membutuhkan waktu yang cukup untuk persiapan.

3. Pemahaman yang kurang tentang mengapa masalah-masalah yang di pecahkan maka siswa kurang termotivasi untuk belajar.

\section{Pemahaman Konsep}

Pemahaman konsep merupakan bagian yang penting dalam proses pembelajaran dan memecahkan masalah, baik di dalam proses belajar itu sendiri maupun dalam lingkungan keseharian. (Hamzah B uno, 2016). Indikator pemahaman konsep adalah sbb:

1. Menyatakan ulang sebuah konsep

2. Mengklasifikasi objek-objek menurut sifat-sifat tertentu (sesuai konsepnya)

3. Memberikan contoh dan bukan contoh dari suatu konsep

4. Menyajikan konsep dalam berbagai bentuk representasi matematika

5. Mengembangakan syarat perlu atau syarat cukup dari suatu konsep

6. Menggunakan, memanfaatkan, dan memilih prosedur atau operasi tertentu

7. Mengaplikasikan konsep atau pemecahan masalah. 


\section{Berpikir Kritis}

Berpikir kritis mempunyai kemampuan untuk berpendapat dengan cara terorganisasi, dan mengevaluasi secara sistematis bobot pendapat pribadi

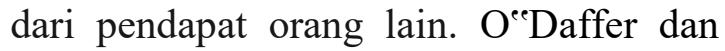
thornquist mengemukakan, berpikir kritis memiliki beberapa tahapan-tahapan sebagai berikut: memahami masalah, melakukan pengkajian terhadap bukti data, asumsi, menyatakan, mendukung suatu kesimpulan, keputusan, atau solusi, menerapkan kesimpulan, keputusan, atau solusi.(enung sumaryati dan utari sumarmo, 2013). Indikator berpikir kritis adalah sbb:

1. Memberikan penjelasan sederhana

2. Membangun keterampilan dasar

3. Membuat inferensi

4. Membuat penjelasan lebih lanjut

5. Mengatur strategi dan taktik

\section{METODE PENELITIAN}

Penelitian ini merupakan penelitian eksperimen semu (quasi experiment) dengan desain penelitian pretest-posttest control design. Rancangan penelitian ini dapat dilihat pada tabel 2 .

Tabel 2. Desain penelitian

\begin{tabular}{cccc}
\hline Kelompok & $\begin{array}{c}\text { Tes } \\
\text { Awal }\end{array}$ & Perlakuan & $\begin{array}{c}\text { Tes } \\
\text { Akhir }\end{array}$ \\
\hline Eksperimen & $\mathrm{T}_{1}$ & $\mathrm{X}_{\mathrm{M}}$ & $\mathrm{T}_{2}$ \\
Kontrol & $\mathrm{T}_{1}$ & $\mathrm{X}_{M}$ & $\mathrm{~T}_{2}$ \\
\hline
\end{tabular}

(Modifikasi Sugiyono, 2008).

Keterangan:

$\mathrm{T}_{1} \quad=$ Tes awal (Pretest)

$\mathrm{T}_{2}=$ Tes akhir (Posttest)

$\mathrm{X}_{\mathrm{m}}=$ Menggunakan model pembelajaran problem based learning (PBL)

$\mathrm{X}_{m}=$ Menggunakan model pembelajaran langsung (Direct Instruction).

Populasi dalam penelitian ini adalah peserta didik kelas X SMA N 1 waway karya lampung timur. Sampel yang digunakan adalah kelas X MIA 1 sebagai kelas eksperimen dan X MIA 2 sebagai kelas kontrol.
Data yang digunakan dalam penelitian ini dikumpulkan menggunakan instrumen tes soal essay Instrumen yang digunakan telah divalidasi oleh ahli untuk melihat keabsahannya. Lembar soal essay digunakan untuk mengukur pemahaman konsep dan berpikir kritis yang diberikan pada awal (pretest) dan akhir (posttest) pembelajaran. Soal yang digunakan mengacu pada berbagai sumber buku pelajaran fisika dengan mengembangkan indikator kemampuan analisis peserta didik. Soal pretest dan posttest yang disusun dengan memiliki indikator dan tipe soal yang berbeda. Sebelum soal digunakan untuk penelitian terlebih dahulu di uji validitas, reliabilitas, daya beda dan tingkat kesukaran. Analisis data menggunakan spss 17.00 untuk menguji normalitas, homogenitas dan hipotesis.

Sebelum diberikan perlakuan berupa penerapan model PBL pada kelas eksperimen dan penerapan model pembelajaran langsung pada kelas kontrol, masing-masing kelas diberikan pretest untuk melihat kemampuan awal pemahaman konsep dan berpikir kritis peserta didik. Setelah itu, dilaksanakan pembelajaran sesuai dengan RPP yang telah disusun. Selanjutnya diberikan posttest untuk melihat pemahaman konsep dan berpikir kritis peserta didik pada akhir pertemuan.

Data yang diperoleh dianalisis secara statistik deskriptif dan analisis statistik inferensial. Analisis statistik deskriptif dilakukan dengan mendeskripsikan data yang diperoleh. Data yang dideskripsikan meliputi nilai rata-rata (mean), standar deviasi, varians, nilai minimal dan nilai maksimal baik untuk data sebelum pembelajaran maupun data sesudah pembelajaran.

Peningkatan pemahaman konsep dan berpikir kritis peserta didik dapat diketahui melalui data dari gain score. Klasifikasi Nilai Gain disajikan pada Tabel 3. 
Tabel 3. Klasifikasi Nilai Gain Menurut Hake

\begin{tabular}{cc}
\hline Nilai Gain & Interpretasi \\
\hline $\mathrm{g}>0,7$ & Tinggi \\
$0,7 \geq \mathrm{g} \geq 0,3$ & Sedang \\
$\mathrm{g}<0,3$ & Rendah \\
\hline
\end{tabular}

(Modifikasi Hake, 1998)

statistik inferensial dilakukan untuk menguji masing-masing hipotesis. Pengujian hipotesis pada penelitian ini menggunakan uji MANOVA dengan bantuan program SPSS 17.0. Data yang digunakan untuk uji hipotesis adalah data gain score pemahaman konsep dan berpikir kritis peserta didik. Sebelum uji MANOVA, terlebih dahulu dilakukan uji prasyarat, yaitu uji normalitas dan uji homogenitas. Uji normalitas dilakukan terhadap data pemahaman konsep dan berpikir kritis peserta didik dengan menggunakan uji Kolmogorov Smirnov test. Hasil uji normalitas data pemahaman konsep dan berpikir kritis peserta didik disajikan pada Tabel 4.

Tabel 4. Hasil uji normalitas

\begin{tabular}{cccc}
\hline Variabel & $\begin{array}{c}\text { Kelas } \\
\text { Eksperimen }\end{array}$ & Kelas Kontrol & Kesimpulan \\
\hline Pemahaman konsep & 0,067 & 0,200 & Berdistribusi \\
Berpikir kritis & 0,106 & 0,063 & Normal \\
\hline
\end{tabular}

Tabel 4, menunjukkan bahwa data pemahaman konsep dan berpikir kritis baik kelas eksperimen maupun kelas kontrol memiliki nilai signifikansi $>\alpha$, maka dapat dikatakan bahwa data berdistribusi normal. Uji homogenitas dilakukan dengan menggunakan uji Lavenne's test. Hasil perhitungan uji homogenitas dari data pemahaman konsep dan berpikir kritis dapat dilihat pada tabel 5 .

Tabel 5. Hasil Uji Homogen

\begin{tabular}{ccc}
\hline Variabel & Sig & Kesimpulan \\
\hline Pemahaman konsep & 0,605 & Homogen \\
Berpikir kritis & 0,814 & \\
\hline
\end{tabular}

Tabel 5 menunjukkan bahwa data pemahaman konsep dan berpikir kritis kelas ekperimen dan kelas kontrol memiliki nilai signifikansi $>\alpha$, maka dapat dinyatakan bahwa data homogen. Setelah dilakukan uji prasyarat, dilanjutkan dengan pengujian hipotesis. Hasil pengujian hipotesis dengan uji MANOVA, yang dapat dilihat pada Tabel 6.

Tabel 6. Hasil Uji Manova

\begin{tabular}{lll}
\hline Hipotesis & Variabel & Sig \\
\hline 1 & Pemahaman konsep & 0,000 \\
2 & Berpikir kritis & 0,002 \\
\hline
\end{tabular}

Berdasarkan Tabel 6, diketahui bahwa Hipotesis 1 , nilai signifikansi $<0,05$, maka $\mathrm{H}_{0}$ ditolak, sehingga dapat disimpulkan bahwa terdapat pengaruh penerapan model PBL terhadap pemahaman konsep. Hipotesis 2, nilai signifikansi $<0,05$, maka $\mathrm{H}_{0}$ ditolak, sehingga dapat disimpulkan bahwa terdapat pengaruh penerapan model PBL terhadap berpikir kritis peserta didik.

\section{HASIL DAN PEMBAHASAN}

Data kemampuan analisis pada penelitian ini terdiri dari data kemampuan analisis sebelum (pretest) dan sesudah (posttest) pembelajaran. Data pretest dan posttest kemampuan analisis disajikan pada Tabel 7.

Tabel 7. Data Pemahaman Konsep Peserta Didik

\begin{tabular}{ccccc}
\hline Data & \multicolumn{2}{c}{$\begin{array}{c}\text { Kelas } \\
\text { eksperimen }\end{array}$} & \multicolumn{2}{c}{$\begin{array}{c}\text { Kelas } \\
\text { kontrol }\end{array}$} \\
\cline { 2 - 5 } & pretest & posttest & pretest & posttest \\
\hline $\begin{array}{c}\text { Mean } \\
\text { Standar }\end{array}$ & 99 & 81 & 60 & 73 \\
deviasi & 10 & 12 & 9,7 \\
$\begin{array}{c}\text { Nilai } \\
\text { min. }\end{array}$ & 36 & 64 & 39 & 54 \\
$\begin{array}{c}\text { Nilai } \\
\text { mak. }\end{array}$ & 75 & 96 & 86 & 89 \\
\hline
\end{tabular}


Berdasarkan tabel 7, diketahui bahwa rata-rata nilai pretest pemahaman konsep kelas kontrol lebih tinggi dari pada kelas eksperimen, yaitu 60 sedangkan kelas eksperimen sebesar 59. Pada saat melakukan pretest, peserta didik kelas eksperimen mengerjakan soal terlebih dahulu, kemudian peserta didik kelas kontrol mengerjakan sesudahnya, terdapat jeda waktu antara kelas eksperimen dan kelas kontrol, sehingga terdapat kemungkinan peserta didik kelas kontrol menanyakan jenis soal pretest kepada peserta didik kelas eksperimen, sehingga kelas kotrol dapat mempersiapkan materi terlebih dahulu.

Nilai pretest posttest pemahaman konsep, rata-rata yang diperoleh kelas eksperimen lebih tinggi daripada kelas kontrol. Telah disajikan pada Gambar 1.

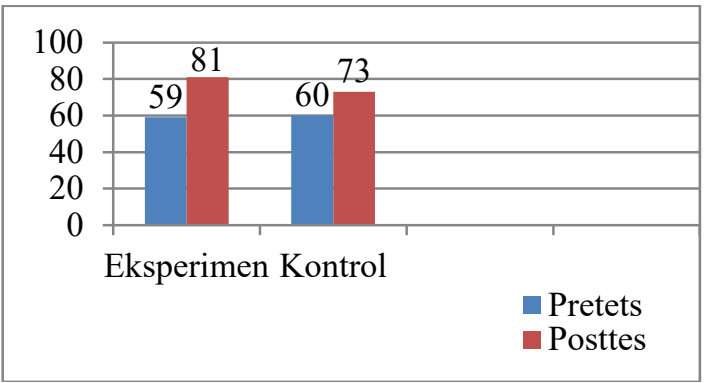

Gambar 1. Grafik pretest-posttets pemahaman konsep kelas eksperimen dan control

Pada gambar1terlihat bahwa nilai rata-rata posttest kelas eksperimen sebesar 81 dan pada kelas kontrol sebesar 73. Sedangkan rata-rata nilai pretest kelas kontrol sebesar 60 dan pada kelas kontrol sebesar 59. nilai pretest- posttest pemahaman konsep, rata-rata yang diperoleh kelas eksperimen lebih tinggi daripada kelas kontrol.

\begin{tabular}{|c|c|c|c|c|}
\hline \multirow[t]{2}{*}{ Data } & \multicolumn{2}{|c|}{$\begin{array}{c}\text { Kelas } \\
\text { eksperimen }\end{array}$} & \multicolumn{2}{|c|}{$\begin{array}{c}\text { Kelas } \\
\text { kontrol }\end{array}$} \\
\hline & pretets & posttes & pretets & posttes \\
\hline Mean & 53 & 80 & 46,6 & 63,67 \\
\hline $\begin{array}{l}\text { Standar } \\
\text { deviasi }\end{array}$ & 14,5 & 9,4 & 14,4 & 10 \\
\hline $\begin{array}{l}\text { Nilai } \\
\text { min. }\end{array}$ & 25 & 65 & 20 & 45 \\
\hline
\end{tabular}

\begin{tabular}{lllll}
\hline $\begin{array}{l}\text { Nilai } \\
\text { mak. }\end{array}$ & 75 & 95 & 75 & 80 \\
\hline
\end{tabular}

Berdasarkan tabel 8, diketahui bahwa rata-rata nilai pretest berpikir kritis kelas eksperimen lebih tinggi dari pada kelas kontrol, yaitu 53 sedangkan kelas kontrol sebesar 46,6.

Nilai pretest posttest berpikir kritis, rata-rata diperoleh kelas eksperimen lebih tinggi daripada kelas kontrol. Telah disajikan pada Gambar 2.

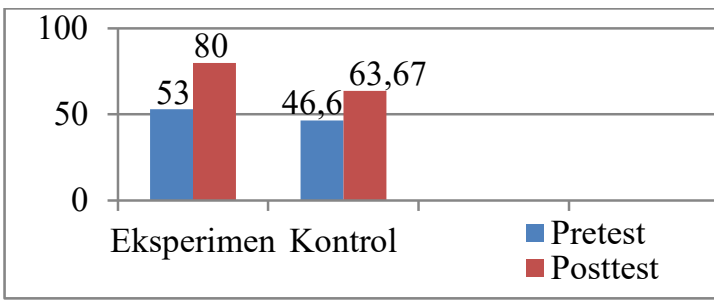

Gambar 2. Grafik Pretest-posttets Berpikir Kritis Kelas Eksperimen dan Kontrol

Pada gambar 2 terlihat bahwa nilai rata-rata posttest kelas eksperimen sebesar 80 dan kelas kontrol sebesar 63,67. Sedangkan rata-rata nilai pretest kelas eksperimen sebesar 53 dan kelas kontrol sebesar 46,6. nilai pretest- posttest berpikir kritis, rata-rata diperoleh kelas eksperimen lebih tinggi daripada kelas kontrol. Selain itu, pemahaman konsep dan berpikir kritis peserta didik dapat dilihat dari gain score. Gain score pemahaman konsep dan berpikir kritis disajikan dalam tabel 9.

Tabel 9. Score Gain Pemahaman Konsep dan Berpikir Kritis

\begin{tabular}{cccc}
\hline Variabel & \multicolumn{2}{c}{ Gain score } & Kriteria \\
\cline { 2 - 3 } & $\begin{array}{c}\text { Kelas } \\
\text { eksperimen }\end{array}$ & $\begin{array}{c}\text { Kelas } \\
\text { kontrol }\end{array}$ & \\
\hline $\begin{array}{c}\text { Pemahaman } \\
\text { konsep }\end{array}$ & 0,51 & 0,31 & Sedang \\
$\begin{array}{c}\text { Berpikir } \\
\text { kritis }\end{array}$ & 0,58 & 0,31 & Sedang \\
\hline
\end{tabular}

Pada Tabel 9, menunjukkan bahwa peningkatan pemahaman konsep dan berpikir kritis peserta didik kelas eksperimen lebih besar dibandingkan kelas kontrol yang ditunjukkan dengan 
nilai gain kedua kelas tersebut. Nilai gain pemahaman konsep kelas eksperimen sebesar 0,51 dan nilai gain pada kelas kontrol sebesar 0,31. Sedangkan Nilai gain berpikir kritis kelas eksperimen sebesar 0,58 dan nilai gain kelas kontrol sebesar 0,31. Masuk dalam kriteria sedang. Perbedaan peningkatan rata-rata nilai gain score antara kelas eksperimen dan kelas kontrol menunjukkan bahwa adanya pengaruh penerapan model PBL terhadap pemahaman konsep dan berpikir kritis peserta didik.

Selain penilai gain score pemahaman konsep dan berpikir kritis, pengaruh penerapan model PBL juga dapat dilihat dari hasil tests of between subject effect yang disajikan tabel 10 .

Tabel 10. Hasil Uji Manova

\begin{tabular}{lll}
\hline Variabel & F & sig \\
\hline Pemahaman konsep & 10.789 & .002 \\
Berpikir kritis & 54.251 & .000 \\
\hline
\end{tabular}

Berdasarkan tabel 10. Diperoleh data pemahaman konsep 0,002 $<0,05$ dengan perbandingan $\mathrm{F}_{\text {hitung }}=10.789$ dan $\mathrm{F}_{\text {tabel }}=$ 3.9819 maka dapat diambil kesimpulan bahwa Ho ditolak dan $\mathrm{H}_{1}$ diterima. Dan data berpikir kritis $0,000<0,05$ dengan perbandingan $\mathrm{F}_{\text {hitung }}=54.251$ dan $\mathrm{F}_{\text {tabel }}=$ 3.9819 maka dapat diambil kesimpulan bahwa Ho ditolak dan $\mathrm{H}_{1}$ diterima.

Berdasarkan hasil pengujian hipotesis dengan menggunakan uji MANOVA, dapat disimpulkan bahwa terdapat pengaruh penerapan model PBL terhadap pemahaman konsep dan berpikir kritis peserta didik. Hal ini disebabkan pada pembelajaran dengan menerapkan model PBL peserta didik dituntut untuk mencari sendiri jabawan dari masalah yang dipertanyakan dengan menggunakan kemampuan berpikir peserta didik agar terbentuk suatu konsep dalam diri peserta didik tentang materi yang dipelajari, sehingga pada saat kegiatan pembelajaran, peserta didik akan menggunakan kemampuan berpikirnya secara maksimal, dalam hal ini kemampuan berpikir kritis. Sedangkan pada pembelajaran dengan menerapkan model pembelajaran langsung, peserta didik lebih banyak mendapat informasi dari pendidik daripada menyelesaikan masalah untuk mendapatkan informasi sendiri, sehingga dalam pembelajaran peserta didik kurang terlatih dalam menggunakan kemampuan pemahaman konsep dan berpikir kritis.

Model problem based learning (PBL) di katakan efektif apabila setelah menggunakan model ini terjadi peningkatan kemampuan pemahaman konsep dan berpikir kritis peserta didik. Kefektifan model pembelajaran problem based learning (PBL) terhadap kemampuan pemahaman konsep dan berpikir kritis peserta didik menggunakan rumus effect size. Berikut hasil perolehan analisis effect size pada tabel 11.

Tabel 11. Hasil effect size

\begin{tabular}{cccc}
\hline $\begin{array}{c}\text { Variabel } \\
\text { Terikat }\end{array}$ & $\begin{array}{c}\text { Effect } \\
\text { Size }\end{array}$ & $\begin{array}{c}\text { Standar } \\
\text { deviasi }\end{array}$ & Kategori \\
\hline $\begin{array}{c}\text { Pemahaman } \\
\text { konsep }\end{array}$ & 0,36 & 0,78 & Sedang \\
$\begin{array}{c}\text { Berpikir } \\
\text { kritis }\end{array}$ & 0,66 & 1,77 & \\
\hline
\end{tabular}

Tabel 11 menunjukkan bahwa perolehan effect size pemahaman konsep sebesar 0,36 sedangkan perolehan effect size berpikir kritis sebesar 0,66 maka termasuk dalam kategori sedang. Hal ini menunjukkan bahwa model PBL memberi effect yang cukup tinggi terhadap pemahaman konsep dan berpikir kritis peserta didik pada mata pelajaran Fisika.

\section{KESIMPULAN}

Berdasarkan hasil analisis, pengolahan data dan pembehasan maka peneliti dapat menarik kesimpulan bahwa:

1. Model pembelajaran Problem Based learning (PBL) menunjukkan perbedaan pada kedua variabel terikat yaitu pemahaman konsep dan berpikir kritis peserta didik SMA pada materi suhu dan kalor. 
2. Model pembelajaran Problem Based learning (PBL) menunjukkan perbedaan pada variabel terikat yaitu pemahaman konsep peserta didik SMA pada materi suhu dan kalor.

3. Model pembelajaran Problem Based learning (PBL) menunjukkan perbedaan pada variabel terikat yaitu berpikir kritis peserta didik SMA pada materi suhu dan kalor.

\section{DAFTAR PUSTAKA}

Ahmad, fandi, s., \& aminah, n. s. (2015). pengaruh pembelajaran fisika pada materi fluida dinamik menggunakan metode problem based learning (pbl) dan inkuiri terbimbing ditinjau dari kemampuan awal dan sikap ilmiah terhadap prestasi belajar dan kreativitas. jurnal inkuiri, vol.4(no.2), h. 77.

Dasa ismaimuza. (n.d.). pengaruh pembelajaran berbasis masalah dengan strategi konflik kognitif terhadap kemampuan berpikir kritis matematis dan sikap siswa smp. jurnal pendidikan matematika, vol.4(no.1), h.2.

Didik juliawan. (n.d.). pengaruh model pembelajaran berbasis masalah terhadap pemahaman konsep dan keterampilan proses sains siswa kelas xi ipa sma negeri 2 kuta tahun pelajaran 2011/2012. program studi pendidikan ipa, h.4.

Enung sumaryati dan utari sumarmo. (2013). pendekatan induktif-deduktif disertai strategi think-pair-squareshare untuk meningkatkan kemampuan pemahaman dan berpikir kritis serta disposisi matematis siswa sma. jurnal ilmiah program studi matematika stkip siliwangi bandung, vol.2(no.1), h.30.

Hamzah b uno. (2016). perencanaan pembelajaran. jakarta: pt.bumi aksara.

M Taufik amir. (2015). inovasi pendidikan melalui problem based learning. jakarta: prenadamedia group.

Parasamya, c. e., \& wahyuni, a. (2017). upaya peningkatan hasil belajar fisika siswa melalui penerapan model pembelajaran problem based learning (pbl). jurnal ilmiah mahasiswa (jim), 2(1), 42-49.

Rifa'i, b. (2013). kontribusi pengelolaan laboratorium dan motivasi belajar siswa kebijakan dan manajemen publik, vol.1(no.1), h.132.

Rusman. (2010). model-model pembelajaran. jakarta: gravindo persada.

Saregar, a. (2016). pembelajaran pengantar fisika kuantum dengan memanfaatkan media phet simulation dan $1 \mathrm{~km}$ melalui pendekatan saintifik: dampak pada minat dan penguasaan konsep mahasiswa introduction study using quantum physics media phet simulation and $1 \mathrm{~km}$ ( student works. jurnal ilmiah pendidikan fisika "albiruni," vol.05(no.1), h.55.

Siregar, purwanto dan seri. (2016). pengaruh model pembelajaran problem based learning (pbl) terhadap belajar siswa pada materi pokok suhu dan kalor di kelas $\mathrm{x}$ semester ii sma negeri 11 medan t.p 2014/2015. jurnal ikatan alumni fisika universitas negeri malang, vol.2(no.1), h.26.

Young and freedman. (2002). fisika universitas edisi kesepuluh jilid 1. jakarta: erlangga.

Yusufhadi miarso. (2004). menyemai benih teknologi pendidikan. jakarta: prenada media group.

Zalia muspita, i. w. lasmawan, dan s. (2013). pengaruh model pembelajaran berbasis masalah terhadap kemampuan berfikir kritis, motivasi belajar, dan hasil belajar ips siswa kelas vii smpn 1 aikmel. ejournal program pascasarjana universitas pendidikan ganesha 
program studi pendidikan dasar, vo.3(no.1), h.2. 